\title{
Meningkatkan Hasil Belajar Siswa Pada Mata Pelajaran Kemuhammadiyahan Melalui Model Pembelajaran Snowball Throwing Di Madarasah Aliyah Muhammadiyah 1 Medan
}

\author{
Dianto*1 $^{2}$ \\ Universitas Muhammadiyah Sumatera Utara*1 \\ "1email:dianto@umsu.ac.id
}

\begin{abstract}
The purpose of this study was to determine student learning outcomes using the Snowball Throwing method on the subject of the Muhammadiyah Academy in Madarasah Aliyah Muhammadiyah 1 Medan. This research is expected to be useful for teachers, schools and future researchers. For teachers, the results of this study are expected to be useful for teachers to improve teaching skills, especially in terms of innovative learning models. The methodology in this research is field research that is obtained through classroom action research (CAR) or called classroom action research. This research method uses two cycles. In the first cycle consists of the planning phase (planning), the stage of action / implementation (action), the stage of observation (observation), and the stage of reflection. Then in the second cycle carried out after learning in the first cycle was analyzed and reflected in order to correct the deficiencies that existed in cycle I. The results showed that the Class X learning outcomes using the Snowball Throwing model were higher than those who did not use them.
\end{abstract}

Artikel Info

Received:

23 January 2020 Revised:

28 May 2020

Accepted:

01 June 2020

Published 04 June 2020

Keywords: Snowball Throwing, Kemuhammadiyahan Learning Outcomes. 


\section{Abstrak}

Tujuan penelitian ini adalah untuk mengetahui hasil belajar siswa dengan menggunakan metode Snowball Throwing pada pelajaran Kemuhammadiyahan di Madarasah Aliyah Muhammadiyah 1 Medan. Penelitian ini diharapkan dapat bermanfaat bagi guru, sekolah dan peneliti selanjutnya. Bagi guru, hasil penelitian ini diharapkan dapat bermanfaat bagi guru untuk meningkatkan kemampuan mengajar terutama dalam hal inovasi model pembelajaran. Metodelogi dalam penelitian ini adalah penelitian lapangan yang datangnya diperoleh melalui penelitian tindakan kelas (PTK) atau disebut classroom Action Research. Metode penelitian ini menggunakan dua siklus. Dalam siklus pertama terdiri dari tahap perencanaan (planning), tahap tindakan/ pelaksanaan (action), tahap pengamatan (observasion), dan tahap refleksi. Kemudian pada siklus kedua dilaksanakan setelah pembelajaran pada siklus pertama dianalisis dan direfleksi dengan tujuan untuk memperbaiki kekurangan yang ada pada siklus I. Hasil penelitian menunjukkan bahwa hasil belajar Kelas X yang menggunakan model Snowball Throwing lebih tinggi daripada yang tidak menggunakannya.

\section{Keywords: Snowball Throwing, Hasil Belajar Kemuhammadiyahan.}

\section{A. Pendahuluan}

Pendidikan merupakan hal yang penting dalam kehidupan manusia. Karena hanya pendidikanlah manusia dapat mengetahui arah dan tujuan kehidupannya sehingga ia dapat mencapai kesejahteran hidup, baik di dunia maupun di akhirat kelak.

Dalam penyelenggaraan pendidikan di sekolah, akan melibatkan seorang guru sebagai pendidik dan siswa sebagai peserta didik yang ditandai dengan adanya interaksi belajar mengajar atau proses pembelajaran.

Dalam bahasa Arab, pendidikan disebut tarbiyah yang berarti proses persiapan dan pengasuhan manusia pada fase-fase awal kehidupannya (Sudrajat, 1999).

Mata pelajaran kemuhammadiyahan sangat penting untuk diterapkan kepada siswa. Karena dengan mata pelajaran 


\section{INTIQAD: JURNAL AGAMA DAN PENDIDIKAN ISLAM}

ISSN 1979-9950 (print) || ISSN 2598-0033 (online), http://jurnal.umsu.ac.id/index.php/intiqad

DOI: 10.30596/intiqad.v12i1.4012

Vol. 12, No. 1 (June 2020)

kemuhammadiyah siswa dapat memahami

Gerakan Muhammadiyah yang ada di Indonesia dan tidak terjadi kesalahpahaman tentang Gerakan Muhammadiyah yang ada saat ini.

Dalam mencapai hasil belajar yang optimal yang merupakan manifestasi dari tujuan pendidikan, tidak terlepas dari peranan guru sebagai pendidik. Maka guru harus dituntut memiliki kompetensi, kecakapan, kreativitas, dan keterampilan dalam mengajar.

Untuk meningkatkan hasil belajar yang lebih baik maka peneliti memperkenalkan sistem pembelajaran "Snowball Throwing" yang artinya lemparan bola salju". Dapat kita pahami bersama bahwa model pembelajaran tersebut merupakan model pembelajaran interaktif.

Adapun pembelajaran interaktif artinya siswa tersebutsangat aktif, siswa dapat dikatakan sebagai subyek dan obyek pendidikan.

Dari keterangan diatas dapat di jelaskan bahwa penelitian yang lebih efektif dalam meningkatkan hasil belajar siswa yaitu dengan menggunakan model pembelajaran Snowball Throwing yang juga mempunyai nilai tanggungjawab serta bernilai positif dalam kehidupan seharihari.

Snowball throwing diterapkan karena model pembelajaran ini menciptakan suasana yang menyenangkan dalam proses belajar dan membangkitkan motivasi siswa dalam belajar. Siswa akan mudah memahami konsep-konsep dasar dan ideide lebih banyak dan lebih baik dengan adanya saling memberi informasi pengetahuan (Djahir, 2014).

Dengan permasalahan di atas, peneliti akan mengadakan penelitian dengan judul "Meningkatkan Hasil Belajar Siswa Pada Mata Pelajaran Kemuhammadiyahan Melalui Model Pembelajaran Snowball Throwing Di Madarasah Aliyah Muhammadiyah 1 Medan"

Sesuai dengan rumusan masalah yang ada, maka yang menjadi tujuan dari penelitian ini adalah untuk meningkatkan hasil belajar siswa dengan menggunakan model pembelajaran Snowball Throwing mata pelajaran Kemuhammadiyahan di MAM 1 Medan pada kelas X.

Hipotesis tindakan yang diperlukan adalah; dengan menggunakan model pembelajaran Snowball Throwing dapat meningkatkan hasil belajar siswa di MAM 1 Medan pada kelas X. 
Pengertian belajar secara psikologis, belajar merupakan suatu proses perubahan yaitu perubahan tingkah laku sebagai hasil dari interaksi dengan lingkungannya dalam memenuhi kebutuhan hidupnya. Perubahanperubahan tersebut akan nyata pada seluruh aspek tingkah laku (Daryanto, 2010).

Kemudian ada beberapa perbedaan tentang belajar sebagai berikut ini:

Lester D. Crow \& Alice Crow dalam (Roestiyah, 1989) menuturkan bahwa belajar adalah perubahan individu dalam kebiasaan, pengetahuan dan sikap.

Oemar Hamalik (2008) menjelaskan bahwa pembelajaran adalah rangkaian kombinasi yang meliputi adanya manusiawi, fasilitas, material, prosedur dan kelengkapan yang saling mempengaruhi dalam tujuan proses pembelajaran.

\section{B. Metode Penelitian}

Penelitian ini termasuk dalam bentuk jenis penelitian lapangan yang datangnya diperoleh melalui penelitian tindakan kelas (PTK) atau disebut classroom Action Research.

PTK adalah penelitian praktis yang dimaksudkan untuk memperbaiki pembelajaran di kelas. Penelitian ini merupakan salah satu upaya guru atau praktisi dalam bentuk berbagai kegiatan yang dilakukan untuk memperbaiki dan meningkatkan mutu pembelajaran dikelas.

Jenis penelitian yang digunakan adalah jenis penelitian tindakan kelas. Penelitian tindakan kelas (PTK) menurut Tampubolon adalah suatu pemecahan masalah yang memanfaatkan tindakan nyata berupa siklus melalui proses kemampuan mendeteksi dan memecahkan masalah (Tampubolon, 2013).

Desain penelitian atau desain studi menurut Restu (2010), dapat didefinisikan sebagai rencana, struktur dan strategi penyelidikan yang hendak dilakukan guna mendapatkan jawaban dari pertanyaan atau permasalahan pendidikan.

Waktu penelitian dilaksanakan pada bulan Oktober-Desember tahun ajaran 2019/2020. Adapun yang menjadi subjek penelitian ini yaitu siswa kelas X MAM 1 Medan Tahun Ajaran 2019/2020. Dalam penelitian ini dipilih satu kelas yaitu siswa kelas $\mathrm{X}$ dengan jumlah 31 siswa terdiri dari 20 pria dan wanita 11 orang.

Penelitian ini dilaksanakan dalam 2 siklus. Secara rinci kegiatan pada masingmasing siklus akan dijabarkan sebagai berikut: 


\section{INTIQAD: JURNAL AGAMA DAN PENDIDIKAN ISLAM}

ISSN 1979-9950 (print) || ISSN 2598-0033 (online), http://jurnal.umsu.ac.id/index.php/intiqad

DOI: 10.30596/intiqad.v12i1.4012

Vol. 12, No. 1 (June 2020)

\section{Siklus I}

Siklus I terdri dari tahap perencanaan (planning), tahap tindakan/ pelaksanaan (action), tahap pengamatan (observasion), dan Tahap refleksi.

\section{Tahap Perencanaan (Planning)}

Pada siklus pertama, perencanaan tindakan (planning) dikembangkan berdasarkan hasil observasi awal. Dari masalah yang ada dan cara pemecahannya yang telah ditetapkan, dibuat perencanaan kegiatan belajar mengajarnya (KBM).

Perencanaan ini persis dengan KBM yang dibuat oleh guru sehari-hari, termasuk penyiapan media, dan alat-alat pemantauan perkembangan pengajaran seperti lembar observasi, tes, catatan harian dan lain-lain. Pada tahap perencanaan yang dapat dilakukan adalah:

a. Merencanakan pembelajaran yang akan diterapkan dalam proses belajar mengajar.

b. Menentukan pokok bahasan

c. Mengembangkan skenario pembelajaran melalui Rencana Pelaksanaan Pembelajaran. RPP disusun dengan pertimbangan dari guru yang bersangkutan. RPP yang dibuat menekankan pada proses pembelajaran yang mengaktifkan siswa, untuk bertanya, memberikan pendapat bahkan menjawab dan menanggapi sebuah pertanyaan. Hal ini sesuai dengan prinsip model pembelajaran snowball throwing yang akan diterapkan.

d. Menyiapkan sumber belajar

e. Mengembangkan format evaluasi

Format evaluasi digunakan sebagai alat pengukur pencapaian kompetensi belajar siswa setelah digunakannya model pembelajaran snowball throwing. Format evaluasi yang dimaksudkan adalah tes kognitif. Pada penelitian ini, yang dipergunakan adalah soal kognitif pilihan ganda.

f. Mengembagkan lembar observasi pembelajaran

\section{Tahap tindakan (Action).}

Tahap ini adalah realisasi dari teori dan teknik mengajar serta tindakan (treatment) yang sudah direncanakan sebelumnya dengan menggunakan model pembelajaran snowball throwing. Pada akhir tindakan dapat memberikan tes sesudah pembelajaran berlangsung.

\section{Tahap Pengamatan (Observation)}

Tahap pengamatan dilakukan pada saat proses pembelajaran berlangsung 
dengan menerapkan model pembelajaran snowball throwing.

\section{Tahap Refleksi (Reflection),}

Refleksi adalah mengingat dan merenungkan suatu tindakan persis seperti yang telah dicatat dalam observasi. Refleksi berusaha memahami proses, masalah, persoalan, dan kendala yang nyata dalam tindakan strategis.

\section{Siklus II}

Siklus kedua dilaksanakan setelah pembelajaran pada siklus pertama dianalisis dan direfleksi. Siklus kedua dirancang untuk memperbaiki kekurangan yang ada pada siklus I.

\section{Perencanaan}

Perencanaan tindakan dilakukan oleh guru berkolaborasi dengan peneliti. Setelah itu dikembangkan perencanaan agar dapat melaksanakan tindakan. Rencana yang dapat dilakukan sama dengan siklus I, seperti berikut:

a. Menyusun perangkat pembelajaran yang akan dilaksanakan dalam proses pembelajaran, antara lain RPP, dan menggali bahan ajar yang lebih luas.

b. Merumuskan langkah-langkah pembelajaran yang terdiri dari kegiatan awal, kegiatan inti, dan kegiatan penutup.

c. Membuat lembar observasi dan evaluasi kognitif. Lembar observasi merupakan lembar pengamatan selama proses pembelajaran untuk melihat keaktifan siswa selama proses pembelajaran berlangsung.

\section{Tindakan dan Pengamatan}

Kegiatan inti dari proses pembelajaran adalah penerapan model pembelajaran snowball throwing. Sama seperti pada tindakan I, pada tindakan II proses pembelajaran juga menekankan pada aktifitas siswa yang terjadi selama kegiatan proses pembelajaran seperti keberanian siswa dalam bertanya, menjawab pertanyaan, mendengarkan dan keberanian siswa dalam menyampaikan pendapat.

\section{Refleksi}

Pada tahap refleksi II akan mengungkapkan hasil pengamatan, baik dari segi aktivitas siswa maupun dari hasil belajar melalui tes.

Langkah-langkah dalam penelitian tindakan ini dengan skema siklus 1 dan siklus 2 sebagai berikut: 


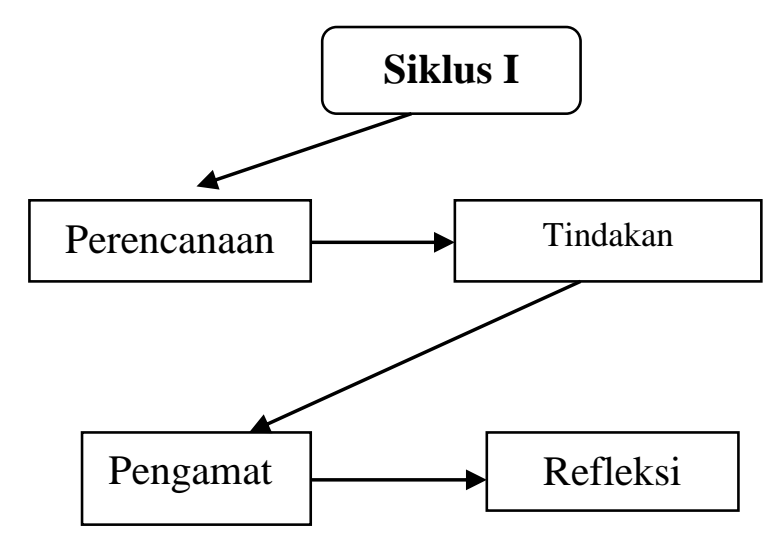

\section{Gambar 1: Skema siklus I}

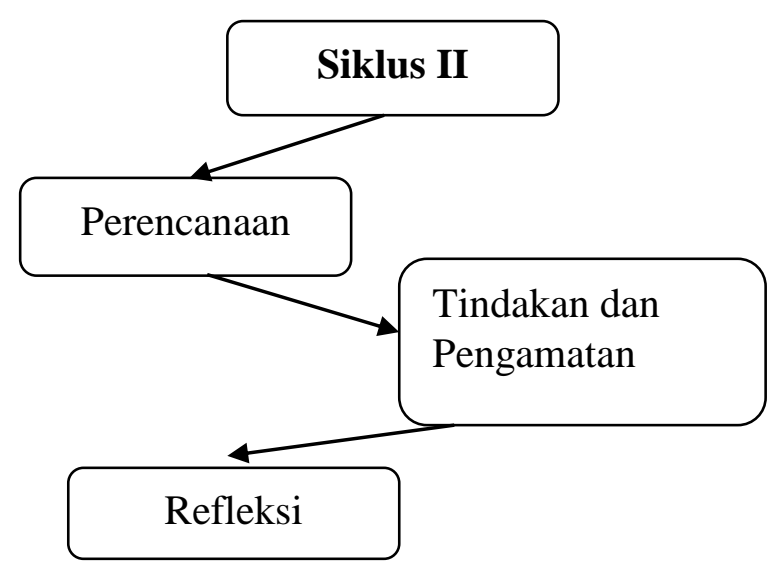

Gambar 2: Skema siklus II

\section{Hasil dan Pembahasan}

Setelah mengobservasi aktivitas siswa dalam proses mengajar selama siklus pertama, maka ditemukan beberapa hal antara lain:

1. Pada aspek kesiapan menerima pelajaran, yang menjadi objek pengamatan yaitu membawa buku paket atau buku catatan dan peralatan tulis. Pada aspek ini dinyatakan, bahwa siswa membawa buku paket atau buku catatan dan $100 \%$ siswa membawa alat tulis.

2. Pada aspek aktivitas siswa dalam proses belajar mengajar yang men jadi objek pengamatan yaitu menjawab pertanyaan yang diajukan guru, mengajukan pertanyaan kepada guru peneliti, memperhatikan penjelasan guru dan memahami materi gerakan muhammadiyah.

Pada aspek ini dinyatakan bahwa, 68\% siswa mampu menjawab pertanyaan peneliti dengan insiatif sendiri, 50\% siswa dapat mengajukan pertanyaan pada peneliti, 70\% siswa memperhatikan penjelasan guru, dan 97\% siswa memahami materi gerakan muhammadiyah. Adapun gambaran persentase ketuntasan dan keaktifan siswa dalam pembelajaran dapat dilihat pada grafik berikut:

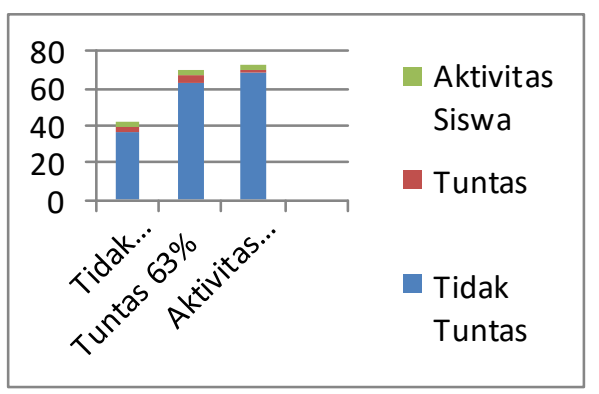

\section{Grafik 1: Peningkatan persentase ketuntasan hasil post-test}




\section{INTIQAD: JURNAL AGAMA DAN PENDIDIKAN ISLAM}

ISSN 1979-9950 (print) || ISSN 2598-0033 (online), http://jurnal.umsu.ac.id/index.php/intiqad

DOI: 10.30596/intiqad.v12i1.4012

Vol. 12, No. 1 (June 2020)

\section{Tahap Refleksi}

Jika dalam ketuntasn hasil belajar siswa tersebut mendapatkan nilai dibawah 75, maka pelaksanaan tindakan kelas pada siklus ini dinyatakan belum berhasil karena belum mencapai $85 \%$.

Hal ini disebabkan karena siswa belum aktif mengikuti proses pemeblajaran secara keseluruhan. Maka untuk memperoleh hasil yang lebih baik lagi peneliti mengadakan perbaikan dalam proses pembelajaran pada siklus kedua, dengan tahapan sebagai berikut:

\section{Tahap Perencanaan}

Dari hasil refleksi siklus 1 dapat disimpulkan, bahwa kegiatan pembelajaran belum optimal sebab masih banyak siswa yang mendapat nilai di bawah 65 (skor minimal). Pada siklus 1 siswa belum berperan aktif secara keseluruhan, meskipun dari segi pelaksanaan tugas menghafal 10 asma'ul husna, selurh siswa melaksanakannya. Maka rencana kegiatan pembelajaran pada siklus II di susun untuk mengatasi permasalahan ini, pada siklus II ini, kegiatan yang di lakukan sama dengan siklus 1 dengan ada nya tambahantambahan kegitan yang sekitar nya bisa membuat siswa lebih berperan aktif.
Adapun gambaran kegiatan yang di lakukan pada proses pembelajaran siklus II adalah sebagai berikut:

a. Menyusun rencana pelaksanaan pembelajaran (RPP) sebagai upaya menyelesaikan masalah.

b. Menyusun soal tes untuk mengevaluasi hasil belajar siswa agar peneliti mengetahui tingkat keberhasilan penerapan model pembelajaran CTL pada siklus II.

c. Membuat lembar observasi untuk melihat aktivitas belajar siswa dalam proses belajar siklus II.

\section{Tahap Pelaksanaan}

Seperti pada siklus I, penelitian mesih menggunakan metode ceramah dan tanya jawab, ditambah dengan metode diskusi.

Kemudian peneliti membuat masyarakyat belajar (learning community), peneliti mengelompokan siswa menjadi beberapa kelompok untuk mendiskusikan materi asma'ul husna, hal ini akan mendorong siswa secara aktif bekerja sama dan memanfaatkan sumber belajar dari teman-teman belajarnya, proses belajar di peroleh dari sharing antara teman, antar kelompok dan antara yang tahu dengan yang belum tahu. Setelah selesai berdiskusi peneliti meminta siswa untuk 
mengumpulkan hasil diskusi merka dan menjelaskannya di depan teman-teman yang lain.

Dari hasil post-test siklus II dapat diketahui bahwa nilai rata-rata kelas meningkat menjadi 83,50. Hal ini menunjukkan penguasaan terhadap materi gerakan muhammadiyah meningkat. Pada siklus II, siswa yang mendapat nilai $\geq 75$ sebanyak 26 orang $(86,67 \%)$ dan sisanya sebanyak 4 orang mendapat nilai $<75$ $(13,33 \%)$.

Berdasarkan tabel di atas, dapat dilihat adanya peningkatan penguasaan terhadap materi gerakan muhammadiyah. Dan rata-rata ketuntasan kelas siswa juga meningkat menjadi 83,50\%.

\section{Tahap Pengamatan}

Pada siklus II, peneliti melakukan observasi selama proses pembelajaran yang dibantu oleh kolaborator, seperti pada siklus sebelumnya.

Pada siklus II, aspek kesiapan menerima pelajaran yaitu membantu buku paket atau buku catatan dan peralatan tulis dinyatakan 100\%. Pada aspek aktivitas siswa dalam proses belajar mengajar yang menjadi objek pengamatan yaitu menjawab pertanyaan yang di anjukan guru peneliti meningkat menjadi $77 \%$, siswa yang mengajukan pertanyaan kepada guru peneliti $83 \%$, siswa yang memperhatikan penjelasan guru $80 \%$, siswa yang menguasai materi gerakan muhammadiyah 97\% dan siswa yang aktif dalam diskusi $90 \%$.

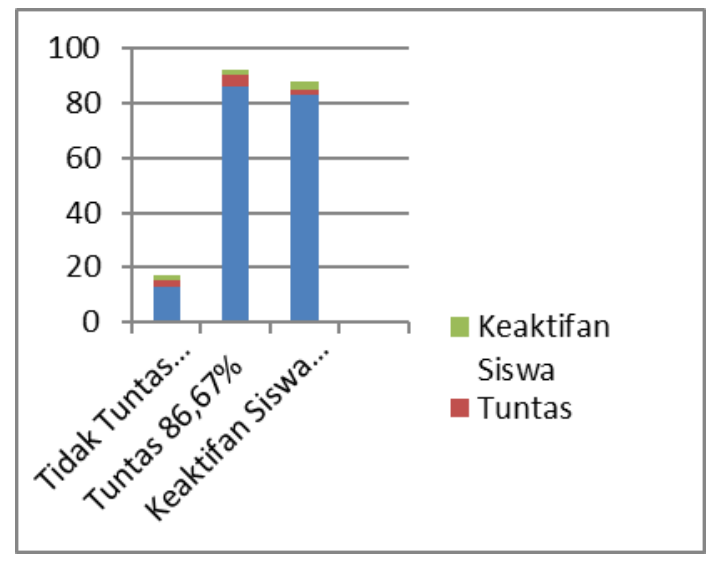

\section{Grafik 2: Hasil evaluasi belajar dan keaktifan siswa.}

\section{Tahap Refleksi}

Peneliti mengajak para siswa untuk memikirkan tentang apa yang baru saja terjadi dan apa yang baru di pelajari, karena pelajaran yang baru di terima akan mudah di aktualisasikapan dalam kehidupan nyata bila pengalaman belajar telah terinternalisasi dalam setiap jiwa siswa.

Berdasarkan hasl penelitian dan pembahasan selama melaksanakan penelitian di MAM I Medan, maka dapat di ketahui dengan menggunakan model pembelajaran snowball throwing pada materi gerakan muhammadiyah dapat meningkatkan hasil belajar siswa. 
Dari hasil evaluasi dan observasi pada siklus I dan II, terjadi peningkatan persentase ketuntasan dan aktifitas Dalam proses pembelajaran, seperti terlihat dalam tabel berikut:

\section{Tabel 1: Persentase Keaktifan Dan} Ketuntasan Kelas

\begin{tabular}{|l|l|c|c|}
\hline No. & Siklus PTK & $\begin{array}{c}\text { Persentase } \\
\text { Ketuntasan } \\
\text { Kelas }\end{array}$ & $\begin{array}{c}\text { Persentase } \\
\text { Keaktifan } \\
\text { Siswa }\end{array}$ \\
\hline 1. & $\begin{array}{l}\text { Kondisi } \\
\text { Awal }\end{array}$ & $\begin{array}{c}17,8 \%(3 \\
\text { Siswa) }\end{array}$ & $47,66 \%$ \\
\hline 2. & Siklus I & $\begin{array}{c}63 \%(19 \\
\text { Siswa) }\end{array}$ & $75,20 \%$ \\
\hline 3. & Siklus II & $\begin{array}{c}86,67 \% \\
\text { (26 Siswa) }\end{array}$ & $83,50 \%$ \\
\hline
\end{tabular}

Tabel tersebut di atas dapat juga dilihat dalam grafik berikut:

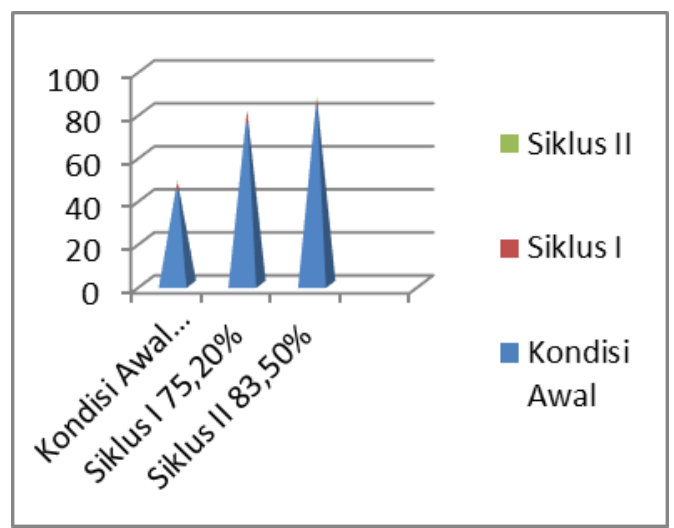

\section{Grafik 3: Aktifitas Siswa Pada Setiap Siklus.}

Setelah menganalisa hasil evalusi dan observasi pada siklus kedua, maka dapat di simpulkan bahwa pembelajaran dengan menggunakan model pembelajaran Snowball Throwing (Lembar Bola Salju) pada mata pelajaran kemuhammadiyahan materi gerakan muhammadiyah dapat meningkatkan hasil dan minat belajar siswa.

\section{Simpulan}

Berdasarkan hasil penelitian pada pembahasan sebelumnya, maka dapat ditarik kesimpulan sebagai berikut:

1. Model pembelajaran Snowball Throwing sangat bermanfaat bagi siswa dalam meningkatkan hasil belajar.

2. Dapat kita pahami bersama bahwa model pembelajaran tersebut merupakan pembelajaran yang efektif dalam mempelajari materi gerakan muhammadiyah bagi siswa kelas $\mathrm{X}$ MAM I Medan.

3. Bedasarkan hasil penelitian, penguasaan siswa terhadap materi gerakan muhammadiyah relatif meningkat. Hal ini dapat di tunjukan dengan tingkat ketuntasan kelas dan aktifitas siswa setelah menggunkan model pembelajaran Snowball Throwing (lempar bola salju).

Sebelum adanya tindakan, siswa yang tuntas belajar hanya 3 siswa $(17,8$ $\%$ ) dan persentasi ke aktifan siswa 47,66 \%. Pada siklus I, siswa yang tuntas dalam belajar meningkat menjadi 19 siswa (63\%). Pada siklus II, siswa yang 
tuntas dalam belajar meningkat 26 orang $(86,67 \%)$ dan persentase keaktifan siswa juga meningkat menjadi $83,50 \%$, sedangkan standar ketuntasan kelas adalah $85 \%$ sehingga PTK menyatakan berhasil.

\section{E. DAFTAR PUSTAKA}

Daryanto. (2010). Belajar dan Mengajar, Bandung: Yrama Widya.

Djahir, A.R., Daud K.W, dan Baharuddin H. (2014). Penerapan Model Pembelajaran Snowball Throwing Berbantu Moke Smile pada Materi Hidrokarbon terhadap Hasil Belajar Siswa Kelas XI SMA Negeri 5 Palu.

J. Akademika Kim. 3 (4), 222-229.

Oemar Hamalik. (2008). Kurikulum dan Pembelajaran. Jakarta: Bumi Aksara.

Restu. (2010). Asas Metodologi Penelitian. Yogyakarta: Graha Ilmu.

Roestiyah, N.K. (2013). MasalahMasalah Ilmu Keguruan.

Jakarta: Bina Aksara.

Setiawan, H. R., \& Masitah, W. (2017). Meningkatkan Motivasi dan Hasil Belajar Mahasiswa Melalui Model
Pembelajaran Kooperatif Group Investigation Pada Mata Kuliah Psikologi Pendidikan di Program Studi Pendidikan Agama Islam FAI UMSU 2016-2017. Intiqad: Jurnal Agama dan Pendidikan Islam, 9(1), 47. 